\section{The role of standardisation in European intermodal transportation}

\section{Intermodal transportation}

Amir Gharehgozli

College of Business and Economics, California State University Northridge, Northridge, California, USA

Henk de Vries

Rotterdam School of Management Erasmus University, Rotterdam, The Netherlands and Faculty of Technology Policy and Management, Delft University of Technology, Delft, The Netherlands, and

\section{Stephan Decrauw}

Rotterdam School of Management Erasmus University, Rotterdam, The Netherlands

\section{Abstract}

Purpose - This paper aims to study the function of standardisation in intermodal transport. It identifies where standardisation helps to improve intermodal transport, who is active in intermodal transport standardisation, what types of standards are needed and what the decision-making process and implementation of standards should be like to positively influence the performance of intermodal transportation.

Design/methodology/approach - An empirical study is designed to carry out this research project. The empirical study starts with a review of the organisations that are responsible for standardisation and intermodal transport, together with the standards that they have developed, and are developing, so far. It continues with analysing the topics where standardisation helps to improve the performance of intermodal transport. The analysis is based on 12 interviews, followed by desk research, to validate the respondents' statements.

Findings - The results show that intermodal transportation should be distinguished in continental and maritime transport, which require different standards. In maritime transport, the hardware aspects of the system are highly standardised. However, further standardisation of information exchange offers potential to improve the quality of transport. For continental transport, challenges appear in the heterogeneity of infrastructure and loading units used in Europe. For both systems, openness and consensus are main requirements for the development of successful standards.

Originality/value - Standards facilitate interoperability, quality and safety of intermodal transportation, which leads to better performance. This has drawn little attention in the literature. This study addresses this gap and focuses on Europe.

Keywords Intermodal transportation, Infrastructure

Paper type Case study

\section{Introduction}

Standards facilitate interoperability, quality and safety of intermodal transportation, which leads to better performance. This has drawn little attention in the literature. This study addresses this gap and focuses on Europe.

(C) Pacific Star Group Education Foundation. Licensed re-use rights only. 
MABR

4,2

The European Conference of Ministers of Transport and European Commission (2001) define intermodal transport as "movement of goods in one and the same loading unit or vehicle, which uses successively two or more modes of transport without handling the goods themselves in changing modes". However, this definition is very broad, and we focus on intermodal road-rail and road-barge transport in Europe. By extending this definition with some important characteristics of intermodal transport, Bontekoning et al. (2004) give the following definition of intermodal transport:

The (European) movement of goods in the same, standardized, loading unit, which successively (by transhipment) uses rail or barge transport for long-haul and road transport for the short-haul leg in a single seamless journey, without handling the goods themselves in changing modes. Furthermore, the journey is characterized by decentralized control because of the multiple actors in the chain.

Intermodal transport plays an important role in EU policy on Europe's future transport network. In the past 30 years, road transport has gained a dominant position in European cargo transport. As shown in Figure 1(a), for the 27 countries of the EU, the current truck/barge/rail split is $75 / 7 / 18$, which has not significantly changed during the past decade (INeS Danube, 2016). Figure 1(b) shows that except The Netherlands with 33 per cent barge transportation, which is due to a highly integrated inland waterway network, truck transportation is dominant among all other countries (Eurostat, 2013).

Road transport is fast, flexible and relatively cheap. However, the EU cannot be reliant on road transport in the future due to capacity constraints. In recent years, the performance of road transport is diminishing because of traffic jams, higher fuel prices, road taxes and the increasing awareness of environmental issues. Among others, it is believed that a modal shift from road to rail and barge will lighten the pressure on European roads. As long as the cost savings on transportation are lower than the extra handling costs, intermodal transport is cheaper than road transport. Moreover, intermodal transport puts less pressure on the environment compared to road transport.

Unfortunately, intermodal transportation faces challenges such as capacity problems, long waiting times, problems with bookings and limited track-and-trace options

Figure 1.

Costs associated with hinterland transportation
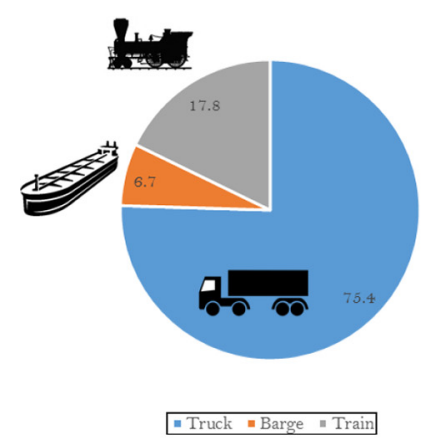

(a)

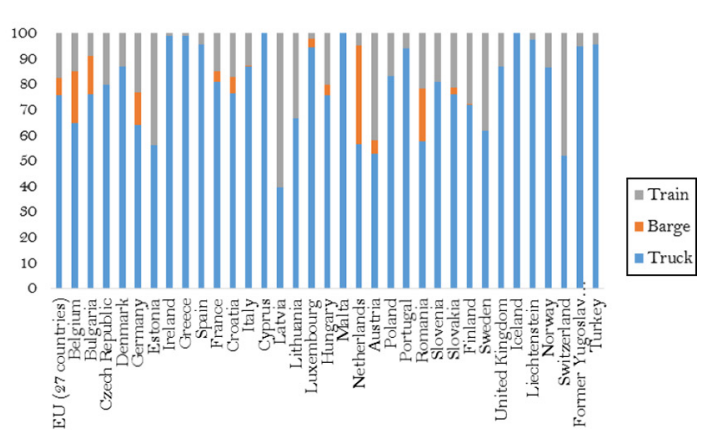

(b)

Notes: (a) Modal split 27 countries of the EU; (b) modal split for each country of the EU in 2013 
(Transport en Logistiek Nederland, 2008). Intermodal transport is complex due to the large number of actors involved. Therefore, better coordination and information exchange is necessary. Aligning and standardising business processes in the intermodal chain might reduce these problems. Standardisation can facilitate interoperability and compatibility of subsystems to improve the performance of the entire system. This study aims to investigate the challenges of creating and implementing standardisation in European intermodal transport chains.

The rest of this paper is organised as follows. First we focus on a literature review of standardisation in intermodal transport in Section 2. Then, we describe our methodology in Section 3. Subsequently, we present the findings of our study in Section 4 and perform an analysis of the potential standardisation possibilities in Section 5. Our conclusions follow in Section 6.

\section{Literature review}

Aim of this review is to define the main concepts discussed in this study and gain further theoretical insight about standardisation in intermodal transport. Furthermore, the study tries to identify gaps in the current knowledge and establish the context of the issue under investigation.

The official definition of a standard is (ISO/IEC, 2004):

[... ] a document, established by consensus and approved by a recognized body that provides, for common and repeated use, rules, guidelines or characteristics for activities or their results, aimed at the achievement of the optimum degree of order in a given context.

Standardisation is the process of making standards. However, standards do not necessary have to be established by consensus or approved by a recognised body. Therefore, the definition of De Vries (1997) is more suitable:

[...] a standard is an approved specification of a limited set of solutions to actual or potential matching problems, prepared for the benefits of the party or parties involved, balancing their needs, and intended and expected to be used repeatedly or continuously, during a certain period, by a substantial number of the parties for whom they are meant.

Literature suggests a positive impact of standardisation on transport performance. An example is the standardisation of loading units (Tomlinson, 2009; Egyedi, 1996, 2001). In the late 1950s, labour costs in ports were high because loading and unloading of vessels required much time. The development of the ISO container led to unitisation of cargo. Now, cargo could be directly transferred from producer to customer without repackaging the goods. This made door-to-door transport possible and led to a significant increase in efficiency. The use of containers enabled automation in the transhipment process, which decreased labour costs. As another example, one could discuss that the lack of common standards causes problems for the railway sector. Traditionally, policies differ per country. Every country has developed its own procedures, infrastructure, etc. This leads to two main problems:

- High costs and low efficiency: The efficiency of the operational process is seriously influenced by border-crossing procedures, differences in infrastructure, locomotives, train driver licences, safety systems, rail gauges, rolling stock, administrative procedures, etc. between countries. This leads to higher transport costs, lower efficiency and a very low level of integration (Meyer, 2012).

- Mistakes due to a lack of cooperation and/or communication: The intermodal transport chain consists of multiple actors who need to effectively and 
MABR

4,2

\section{4}

efficiently exchange information and data in order for the process to run smoothly. A lack of harmonised information systems and data exchange protocols are the main cause for this problem (Bask et al. , 2001; Reis et al. , 2012; Dullaert et al. , 2009).

Many scholars opt for further standardisation to harmonise different transport modes to improve the quality of intermodal transport. According to Bontekoning and Priemus (2004): "innovations in technological and organizational aspects are necessary if the market share of intermodal transport is to expand". Many see an important role for inter-organisational coordination, integration of operations and information networks. Table I shows which dimensions in intermodal transportation could be standardised. Based on our study and the outcomes of the interviews discussed in Section 4, the fields with most potential for standardisation seem to be infrastructure, information and data exchange and equipment within the intermodal transportation chain. In terms of infrastructure, some important steps have already been made including the development of standards for train control and command systems, called ERTMS (European Rail Traffic Management System). But looking at the recent studies which address this problem, there is still a lot to improve. Because of the multi-actor environment of intermodal transport, it is important that data and

\begin{tabular}{|c|c|c|}
\hline Dimension & Standards for: & Authors \\
\hline \multirow[t]{2}{*}{ Infrastructure } & Lay-out, planning and design & Silborn (2013), and Motraghi (2013) \\
\hline & $\begin{array}{l}\text { Technical: Signalling and power } \\
\text { systems }\end{array}$ & $\begin{array}{l}\text { Sakalys and Palšaitis (2006), Reis et al. } \\
\text { (2012) }\end{array}$ \\
\hline \multirow[t]{3}{*}{ Data and information } & Information exchange & $\begin{array}{l}\text { Bask et al. (2001), Dullaert et al. (2009), Reis } \\
\text { et al. (2012), Sys and Vanelslander (2011), } \\
\text { Stölzle et al. (2009), Silborn (2013) }\end{array}$ \\
\hline & Documents & Motraghi (2013), and Marinov (2009) \\
\hline & Tracking units & Motraghi (2013) \\
\hline \multirow[t]{3}{*}{ Equipment } & Vehicles/rolling-stock & $\begin{array}{l}\text { Janic (2001), Bontekoning and Priemus } \\
\text { (2004), Tsamboulas et al. (2007), Marinov } \\
\text { (2009) }\end{array}$ \\
\hline & Loading units & $\begin{array}{l}\text { Bask et al. (2001), Janic (2001), Van de Lande } \\
\text { and Henriques (2006), Tsamboulas et al. } \\
\text { (2007), Konings (2008), Marinov (2009), } \\
\text { Silborn (2013) }\end{array}$ \\
\hline & Packaging & Bask et al. $(2001)$ \\
\hline \multirow[t]{2}{*}{ Security and safety } & Security & $\begin{array}{l}\text { Silborn (2013), Sakalys and Palšaitis (2006), } \\
\text { Marinov (2009), Reis et al. (2012) }\end{array}$ \\
\hline & Safety & Eisenkopf et al. (2006) \\
\hline Services & Overall reliability and transit times & Silborn (2013), Sakalys and Palšaitis (2006) \\
\hline Terminal & $\begin{array}{l}\text { Planning, design, processes, } \\
\text { services, systems, equipment }\end{array}$ & $\begin{array}{l}\text { Van de Lande and Henriques (2006), Silborn } \\
\text { (2013) }\end{array}$ \\
\hline \multirow[t]{2}{*}{ Contracts } & Common contracts & Reis et al. (2012) \\
\hline & Liability rules & $\begin{array}{l}\text { Marinov (2009), Van de Lande and } \\
\text { Henriques (2006) }\end{array}$ \\
\hline Pricing & Infrastructure duties/taxes & Stölzle et al. (2009) \\
\hline \multirow[t]{3}{*}{ Labour } & Working conditions & Stölzle et al. (2009) \\
\hline & Routines & Bask et al. (2001) \\
\hline & Training & Van de Lande and Henriques (2006) \\
\hline Environmental & Noise & Reis et al. (2012) \\
\hline
\end{tabular}

Table I.

Possible areas for standardisation

\section{Documents \\ Tracking units}

Loading units

Packaging

Safety

Planning, design, processes, Corvices, systems, equipment Common contracts

Infrastructure duties/taxes

Routines

Noise
Silborn (2013), and Motraghi (2013)

Sakalys and Palšaitis (2006), Reis et al. Bask et al. (2001), Dullaert et al. (2009), Reis et al. (2012), Sys and Vanelslander (2011), Stölzle et al. (2009), Silborn (2013)

Motraghi (2013) Janic (2001), Bontekoning and Priemus (2004), Tsamboulas et al. (2007), Marinov (2009) and Henriques (2006), Tsamboulas et al. (2007), Konings (2008), Marinov (2009), Silborn (2013) Marinov (2009), Reis et al. (2012) Eisenkopf et al. (2006)

Van de Lande and Henriques (2006), Silborn (2013)

Reis et al. (2012)

Marinov (2009), Van de Lande and

Henriques (2006)

et al. (2009)

Bask et al. (2001)

Reis et al. (2012) 
information is exchanged on time, accurately, and efficiently to ensure the seamless journey through the chain. Many studies have found that cooperation and communication between actors is poor, while current information systems are often incompatible. Creating standards in IT systems (e.g. booking, tracking and tracing and invoicing processes), communication flows, data exchange (e.g. XML or EDI), interfaces and procedures creates opportunities for centralising information, leading to a one-stop-shop solution (Sakalys and Palšaitis, 2006).

Many studies also concern standardisation of equipment in intermodal transport. Currently, loading units are optimised for a single mode (Meyer, 2012; Woxenius and Bergqvist, 2011). In intercontinental transport, the ISO container is used, while in intraEuropean road transport, trailers are often used. Road transport prefers to use semi-trailers, as they are lighter and can load 33 euro-pallets. For deep-sea and inland navigation, stackability of loading units is very important, therefore these modalities prefer to use ISO containers. For rail transport, containers are also more attractive. They can be loaded on flat waggons, are secured by twist locks and are simple to lift. Regular trailers, however, cannot be lifted on trains (they need extra reinforcement) and pocket wagons with a king-pin box are needed to transport the trailers by train.

An important question this study tries to answer is on what level standards should be developed and adopted? Not much has been written about this in literature, but ideas do exist. Standards for freight transport are developed at the national, European (European Committee for Standardization CEN) and international levels (International Organization for Standardization ISO). According to Silborn (2013), standardisation should be established at European and international level because of the long-distance, border-crossing nature of intermodal transportation. Most scholars reason that standards should be set on a European level (Marinov, 2009; Janic, 2001; Van de Lande and Henriques, 2006). In the future, it is expected that rail transport between Europe and Asia will show growth potential, but for now, the EU transport policy focuses on creating a European-wide unified transport network (Merkel, 2018). Therefore, setting standards at the European level seems to be the most logical step.

All in all, in the standardisation literature, ICT gets a lot of attention, whereas other fields of standardisation, including (intermodal) transport, are hardly addressed. There is still a lack of knowledge on standardisation practices. Despite the deep literature on port operations (Vis and De Koster, 2003; Carlo et al., 2014a, 2013, 2014b; Gorman et al., 2014; Gharehgozli et al., 2014a, 2014b, 2015, 2016, 2017a, 2017b, 2017c, 2017d; Gharehgozli and Zaerpour, 2018; Galvao et al., 2018; Steenken et al., 2004; Stahlbock and Voß, 2008) and shipping operations (Sharifyazdi et al., 2018; Mileski et al., 2018; Lee and Song, 2017; Fransoo and Lee, 2013; Christiansen et al., 2007, 2004, 2013; Meng et al., 2014; Tran and Haasis, 2015; Ronen, 1993), the intermodal research field is still in a pre-paradigmatic phase, especially regarding standardisation. Furthermore, most research on standardisation in intermodal transportation is practice-oriented. These studies do recommend standardisation to be used to improve interoperability of European intermodal transportation, but do not further elaborate on this topic. Especially, studies about stakeholders, their stakes and the decisionmaking process are missing (Caris et al., 2008; Egyedi, 1996). By applying current knowledge of standardisation on intermodal transportation, this study tries to bridge this gap.

\section{Methodology}

In this section, we introduce the most important concepts to be used in the case study, we give some additional background information on these topics, and identify the relations 
MABR

4,2

156

between these theoretical concepts. Finally, at the end of the section, we discuss how the empirical data, including the interview process, has been collected.

\subsection{Types of standards}

A distinction can be made between basic standards, requiring standards, and measurement standards (de Vries, 1997). Requiring standards can be distinguished in performance standards and standards that describe solutions. Another possible subdivision of requiring standards concerns the distinction between: interference standards, compatibility standards and quality standards. Compatibility standards are always descriptive; interference and quality standards can be performance standards and solution-describing standards. In fact, measurement standards are a particular kind of requiring standards, namely, standards that describe a solution for measuring. Most standards concern technical topics, other topics include services and management systems. In many standards, preference ranges are laid down. This study focuses largely on compatibility standards: standards that aim to match different objects or systems to each other. Indeed, many scholars in the field of intermodal transportation mention the lack of interoperability and/or compatibility of the European intermodal transportation system. The differences between transport modes and between national transport systems have led to poor performance of intermodal transportation, while most intermodal transport routes have to cross national borders. Compatibility standards can create solutions for problems in the matching between two processes or entities.

\subsection{Modes of standardisation}

Wiegmann (2013) distinguishes three modes of standardisation: market-based, committeebased and governmental. In market-based standardisation, standards result from a battle between competing actors. In committee-based standardisation, standards are the result of an agreement between stakeholders represented in a committee. In governmental standardisation, government intervenes in standards setting or imposes a standard. For inter-model transport in Europe, committee-based standardisation is most important, more in particular standards setting by two formal Standards Development Organisations (SDOs) at the international and European level, ISO and CEN, respectively. The main principles of formal standardisation are: openness, decision-making based on consensus, transparency and coherency. Formal standards are set carefully with involvement of different stakeholders. These standards are updated every five years, if necessary. However, the process is rather slow because of the consensus-based decision-making and the option to provide comments at different stages.

Establishing successful compatibility standards is not easy because each modality or European member state has its own transport subsystems with different characteristics. They all have a certain number of users of the subsystems, this is called the installed base. When a European standard is established, users must switch from their current system to the new common European solution, which leads to switching costs. This is only attractive when the profits of the new standard (better performance due to a higher level of interoperability) exceed the costs of switching. When this is not the case, a lock-in occurs: the different countries stick to their current standards. They are waiting for each other to adopt the new standard. When early adopters adopt the new standard, other parties may step on the bandwagon. Then the new European standard may become the dominant design and for every country, it will become attractive to hop on the bandwagon as this leads to economies of scale because of network effects. The latter means that the functionality of a standard or system becomes more attractive for an individual user increases when more users implement it. 


\subsection{Interoperability}

Interoperability can be defined as:

[...] the ability of systems, units or forces to provide services to, and accept services from, other systems, units or forces and to use the services so exchanged to enable them to operate effectively together without altering or degrading the information exchanged (Clark and Jones, 1999).

To put it simply, two systems are interoperable when they are able to effectively work together. Compatibility standards aim to improve interoperability of a system. But a compatibility standard is not a sufficient condition to achieve interoperability according to Lehr (1995). He states that: "Traditional SDOs are sometimes perceived as too slow and often approve standards that fail to guarantee interoperability. Producers and customers often need to expend significant resources on conformance testing". If some restrictions for particular parameters are not specified, users can claim compliance to a standard without realising interoperability. So a well-specified standard has a positive influence on system interoperability, but the problem is that it is very difficult to specify a good standard which does not leave any room for different interpretations.

\subsection{Data collection}

The foregoing can be summarised as follows. Compatibility and quality standards are expected to have a positive influence on the interoperability of the European intermodal system. Interoperability can then lead to improved performance in terms of lead times, price, reliability, etc. The empirical part of our study focuses on these relations. We collect data through personal interviews with actors in intermodal transport in Europe. Empirical data stem from multiple sources. First, a pre-study was done, including an interview with an expert who works in the intermodal rail industry, and visits to container terminals. Our sampling strategy was networking sampling. The limitation of this sampling method is the difficulty of generalising the research conclusions to other instances. Fortunately, our sample consists of a diverse set of expert stakeholders from intermodal transport so the bias, which often occurs in snowball sampling, is likely to be limited. Finally, 12 semi-structured interviews have been carried out from different companies including rail carriers (three companies), barge operators (two companies), intermodal operators (two companies), terminal operators (one company), logistic service providers (two companies), transport research organisation (one company) and trade association of shipping and transport companies (one company). The interview questions can be found in Appendix A. Additionally, background information and statistics about the actors were also obtained, such as data about the number of employees, turnover, target markets and the different products or services of companies that participate. To ensure a high level of reliability and internal validity, respondent validation has been used.

\section{Empirical results}

This section presents and analyses the outcomes of the interviews. Data across all respondents have been analysed to find similarities and differences between respondents. We distinguish between (Cosmos Project, 2013):

- Maritime intermodal transportation: This includes intermodal transport between deep-sea terminals from and to the European hinterland.

- Continental intermodal transportation: This includes intermodal transport between European consignor and consignee, i.e. transport within Europe. 
MABR

4,2

\subsection{Information exchange and communication}

The main issue in intermodal transport, according to the respondents, is the exchange of information within the supply chain. Better communication and exchange of information between stakeholders would improve the performance of intermodal transportation, in maritime and continental intermodal transport. Information-related problems include:

- Double information: Information exchange between organisations is not efficient because each organisation in the intermodal supply chain uses its own information system, with their own communication language, software and structure.

- Wrong information: Due to the differences between information systems and their structure and language, other mistakes may also occur: wrong input. It must be clear what information is needed in the input fields. For example, a barge operator mentioned that clients often tell the planners that the container to be transported is a 40 -ft container. But the client forgets to mention that in fact it is a $40-\mathrm{ft}$ pallet-wide container, which is a few centimetres wider.

- Timely information: Often, information is not exchanged in time.

- The demand for information is unknown: Often, organisations do not know which information they need to exchange.

\subsection{Loading units}

In continental transport, different types of loading units are used. In maritime transport, this is not an issue; the standard ISO 20-ft and 40-ft containers are common. Deep-sea vessels, transhipment technologies (e.g. cranes) at terminals and transport modes (barges and train wagons) at inland modalities are perfectly adapted to the dimensions of these ISO containers. Therefore, the process of (un-)loading vessels and transhipping the cargo to trucks, trains and barges is now much more efficient than before the use of standardised containers.

Loading units in continental intermodal transport are more diverse. The first reason is that in continental intermodal transport, typically trucking companies shift cargo from the road to barge/rail, on routes over longer distances where substantial volumes are available. In traditional trucking, semi-trailers are often used. These are able to load more euro-pallets compared to the $40-\mathrm{ft}$ containers used in maritime transport. So for continental intermodal transport to be competitive with road transport it is necessary to use units larger than $40 \mathrm{ft}$. Second, while continental intermodal transport must compete with road transport, it is important to be flexible so carriers can fulfil the diversified demands of continental European clients. Finally, the loading units are owned by various parties, in contrast to the dominance of deep-sea carriers in maritime transport. Loading units in continental transport can be owned by shippers, trucking companies or the intermodal operators.

The following loading units are used in rail transport:

- Container: They are standardised ISO containers, available in lengths of 20, 30, 40 and $45 \mathrm{ft}$. Tank containers often have different lengths.

- Semi-trailer: They are truck trailers that can be loaded on trains, vertically (lifting) or horizontally (driving the units on the wagons).

- Swap bodies: They are light loading units which cannot be stacked.

If barges are involved in the intermodal transport chain, mostly transport containers are used but these differ in length and height which leads to problems. For barge transport, 
continental transport is more problematic compared to maritime transport: It is easy to load a vessel with only $20^{\prime}$ and 40 -ft containers but the different container sizes used in continental transport lead to inefficient use of cargo space.

The same problem applies for rail transport: traditionally flat wagons had a length of 60 $\mathrm{ft}$, so one $20^{\prime}$ and one 40-ft container could be loaded on one wagon. Due the increased popularity of $45-\mathrm{ft}$ containers, modern wagons are now $90 \mathrm{ft}$ long. But when only 20 'or $40-\mathrm{ft}$ containers are used, some space is left unused.

\subsection{Infrastructure}

Problems in infrastructure are still significant in rail transport. Many technical standards have been developed to improve the interoperability of the European rail network but these are not yet used throughout Europe. Examples include the standards for a single European safety control system and for the electrical power network. Due to the high investment costs these standards cannot be implemented throughout Europe overnight. In The Netherlands, the European standards are implemented on new tracks but not yet on older parts of the railway system. As a consequence, Dutch locomotives must be equipped with both the ERTMS and the national system (ATB). Furthermore, multi-system locomotives are needed, fit for 1,500 and 25,000 V. Even worse, they have to be equipped with additional systems to enable them to drive in other countries.

\section{Need for standardisation}

From the previous section, we can conclude that remaining problems in intermodal transportation relate to loading units, infrastructure and information exchange. In this section, we deal with the decision-making processes, performance and types of standards that are necessary to solve these problems.

\subsection{Loading units in intermodal transportation}

5.1.1 Stakes. Each transport modality has its own preferences when it comes to loading units:

- Road transport/shippers: In European road transport, semi-trailers are the preferred loading unit. These units have a maximum length of $13.6 \mathrm{~m}$ and are wider than ISO containers. This allows to carry more euro-pallets. Regular semi-trailers are not stackable because of insufficient strength. This leads to a lower tare weight which results in lower fuel costs or the opportunity to load heavier cargo. Transhipment to other modalities is not possible because regular semi-trailers cannot be lifted. Shippers also prefer trailers because continental intermodal transport competes with road transport. Shippers do not want to use two containers if they can also pack their pallets in one semi-trailer.

- Rail transport: In intermodal rail transport, swap bodies and ISO containers are a good option. These units do not need to be stackable and can be lifted on flat wagons. Swap bodies have the same dimensions as semi-trailers so they have a higher capacity compared to ISO containers. Special intermodal semi-trailers exist, but they need grapple arms to be lifted and pocket train wagons are needed to fit the wheels of the semi-trailers. Therefore swap bodies and containers are easier for rail transport.

- Barge transport: The ship cells of barges are adapted to the standardised 20ft and 40ft ISO-containers. These are not only used in intercontinental deep-sea transport, but also in the maritime intermodal transportation to and from the European 
MABR

4,2

160 hinterland. ISO containers are stackable which makes them the best solution for barge transport.

5.1.2 Type of standard and decision-making process. Interviewees prefer to develop standards on a European level, while these standards are targeted for the European market only. It aims to reduce the number of different intermodal loading units on the European continent. The EU attempted to develop a proposal for a directive on intermodal loading units in 2004, i.e. COM (2004) 361 (European Commission, 2004).

5.1.3 Implementation/performance. The European Intermodal Loading Unit (EILU) can combine the strengths of swap bodies and containers. They can be stacked but have less deadweight than ISO containers, they have the same pallet capacity and dimensions as swap bodies and can be lifted from the top like ISO containers. Therefore the EILU can be used in both barge and rail transport, opposite to swap bodies and semi-trailers which are used in road-rail transport. The EILU is particularly suitable for barge transport because the units will be stackable swap bodies. But for the most common combination of intermodal transport on the continent, road-rail, the EILU has no added value because units do not need to be stacked and then a regular swap body is more efficient because it has a lower deadweight and can be loaded from both the back and from sides of the unit.

Another reason why one single loading unit will be suboptimal is that continental intermodal transport must compete with road transport, which is very flexible. For example, in road transport, longer heavier vehicles (LHVs) which can load up to 60 tonnes and have a length of $25.25 \mathrm{~m}$ will possibly be allowed for international transports within the EU. This is a direct threat to continental intermodal transport:

- LHVs require new investments in road infrastructure which come at the expense of investments in rail infrastructure.

- LHVs are detrimental for the entire society. They do more damage to the current road infrastructure because of their weight and have higher $\mathrm{CO}_{2}$ emissions.

\subsection{Infrastructure in intermodal transportation}

Next to the heterogeneity in loading units, continental rail transport also deals with great differences in rail infrastructure within Europe.

5.2.1 Stakes. Currently stakeholders compromise between stakes on a national and European level.

- National stakes: Traditionally, rail infrastructure and technical systems are specified on a national level. Safety systems, signalling systems and power systems differ per Member state. Some countries even have a rail gauge that deviates from the standard ISO dimensions.

- European stakes: The EU aims for a single rail market. Technical standards have been developed to improve the interoperability and efficiency of the rail network. The European stake is therefore to standardise infrastructure and technical systems at a European level.

5.2.2 Level of standardisation. Currently, standards for rail infrastructure are developed at a European level, mostly by the European standardisation organisations Comité Européen de Normalisation (CEN), Comité Européen de Normalisation Electrotechnique (CENELEC) and European Telecommunication Standards Institute (ETSI). The ISO containers have been developed for global use. Next to that, CEN developed standards for European Intermodal 
Loading Units and European swap bodies. When more standards are created, world-wide standardisation is preferred because European organisations want to have influence in the Asian markets, where most containers and materials are being produced. Furthermore, organisations are now investing in rail connections between Europe and Asia to compete with maritime deep-sea transport. Therefore the development of the "hardware" aspects in rail transport should be developed by ISO committees in the future.

5.2.3 Implementation/performance. Many standards have been developed already to improve the homogeneity of the European intermodal rail market. However, implementation of these standards on infrastructure is very expensive; therefore, it takes many years before a standard it implemented throughout Europe. An example is ERTMS; this system is often only equipped on new rail tracks. Implementing it on tracks that are already in use causes a temporary decrease of capacity due to the track work. Next to that, it is impossible to implement such a system on all rail tracks at once. In The Netherlands the new rail tracks are equipped with ERTMS, but older lines are still equipped with ATB. So before ERTMS is implemented everywhere, multi-system locomotives are necessary. Thus, here we can also identify the entrapment between the national and European stake. In the short term the railway companies do not want the loss of rail capacity, but in the long term a uniform rail infrastructure would increase efficiency and make multi-system locomotives redundant. Another example is the connection between the main Dutch cargo track (Betuwelijn) and the German railways. For a long time, the Germans were not willing to invest in an extra rail track to improve the throughput because Germany has to make the financial investments but the Port of Rotterdam benefits from the project. When the connection at the border is improved, rail transport from the Port of Rotterdam will improve, which is a strategic advantage against German ports. These examples show that organisations and countries are often still concerned with their individual stakes instead of the joint European stake. The switching costs from the current situation to European standards are still perceived as very high, it is important that a significant installed base is built so that the other parties will also make the shift.

Respondents see an important role for the EU as the main party to initiate the shift to European standards. Single countries or organisations are often reluctant to invest, they are afraid that other parties will benefit from their investments. When a neutral organisation like the EU will initiate investments the market is willing to cooperate and switch standards. The view of the respondents complies with the strategy of the EU. Via its trans-European transport network (TEN-T) plan, the EU invests money in the implementation of standards. They choose important European rail corridors (TEN-T), which will be designed according to the latest European technical standards. On these corridors, ERTMS must be implemented by 2050. Furthermore, by 2030, the nominal track gauge of $1,435 \mathrm{~mm}$ must be implemented. Here, the freight lines must be equipped to allow for 22.5 ton axle load, the line speed should be $100 \mathrm{~km} / \mathrm{h}$ and trains with a length of $740 \mathrm{~m}$ must be able to run on the tracks (Railcargo, 2013). By investing in the interoperability of the most important European railroads, the EU tries to build an installed base for the technical standards created in recent years. But the respondents are afraid that the implementation of the standards will not be successful. The timespan for these standards is so extensive that it is possible that by 2050 , already newer and better systems exist. Therefore, the respondents are afraid that the European rail market will never have one single system.

\subsection{Information exchange in intermodal transportation}

This section describes the role of information exchange standards in solving this problem. First of all, the three information platforms established in The Netherlands will be introduced. 
MABR

4,2

\section{2}

- Portbase: The Port Community System of the Port of Rotterdam is an information platform that aims to be the Dutch national Port Community System and also should collaborate with other European port systems. Portbase is a neutral platform with a broad support from parties in the port. This information system provides different services to allow participants to share information with each other.

- Neutral Logistics Information Platform (NLIP): NLIP is a neutral information platform for Dutch logistics firms. It connects different systems to standardise information exchange and make it more efficient. The platform will connect Portbase, Cargonaut (information system of Schiphol Airport) and Digipoort (information system of the Dutch Government).

- NextLogic: NextLogic is an initiative to improve performance of barge transport between the Port of Rotterdam and the hinterland by means of better coordination of communication and planning, replacing bilateral communication and planning.

5.3.1 Stakes. For information exchange in intermodal transport three levels of stakes can be identified:

(1) Individual stakes: When all information is available for each organisation, some organisations will have to rethink their core business. Expeditors make money by organising transport for their clients. When everything is transparent and all options are known there is less need for their services. When information can be seen by other parties, they may use their competitors' information for competitive reasons. Therefore companies are reluctant with whom they share what information. Furthermore, transparency beholds responsibility. When a client is billed for two days of transport whereas the cargo could have been transported in one day, the operator will be held accountable.

(2) Stakes of the port: The port should facilitate efficient transport of cargo into and out of the port. Better cooperation between stakeholders and more efficient information exchange will improve the port's performance. As a consequence, more shippers will choose to import and export their cargo via this port.

(3) Stakes of the European and global organisations: Large firms that are active globally are better off when they are able to deliver the same set of information to all ports and can do this in one format. If every European port is developing its own Port Community System and each National Customs organisation demands different sets of information, globally operating corporations need to adapt to different systems. Their operational efficiency will improve when Port Community Systems and information requirements would be standardised on a European or worldwide level.

5.3.2 Type of standards. For information exchange, different types of standards apply. First off, there are standard communication platforms. For example, Portbase is now the standard Port Community System for Dutch port. Secondly, there are standard communication languages like EDI, XML, etc.

According to the respondents, the communication platforms must be a national de-facto standard which could later on be used for formal European or world-wide standardisation. Portbase and NLIP intend to become the standard communication platform for, respectively, the Dutch Ports and the entire Dutch logistics industry. An installed base of users of these information systems is being created now. The initiators do not care which underlying communication standards are used by different systems. Their goal is to connect all 
information systems, regardless of which standards are used. Potential participants must be convinced of the added value of sharing information with chain partners. So at this moment, the information platforms aim to be a de-facto meta-level standard for information sharing in intermodal transport.

The European Port Community Systems Association aims to "promote the highest possible standards in European Port Community Systems". This shows that the different European countries see the importance of standardising port community systems on a European level. This will make it easier for firms active in multiple European ports to exchange information with port authorities and customs. The respondents advise that standards are developed on a world-wide level because logistics organisations communicate with each other on a global level.

5.3.3 Implementation/Performance. The respondents all mentioned the difficulties actors have to shift mentally from individual stakes to the joint stakes of the port. The switching costs from the organisations' current systems to joint systems are oftentimes perceived as too high. The benefits in the long-term do not weigh up to the investments on the short-term. They need to get convinced that providing data to other firms and investing in connections between information systems will profit them and the other organisations in the port in the long run. According to the respondents, the awareness of the joint stakes is improving. An increasing number of organisations use Portbase services and there are new initiatives and projects to improve information sharing, e.g. NLIP and Nextlogic.

The use of coordinated communication platforms has a number of benefits.

- Improved coordination: While information can be collected from a shared information platform, less bilateral communication is necessary, so communication can be integrated and coordinated throughout the chain.

- Lower transaction costs: When information is submitted to a shared platform by one party, every authorised actor has access to this information. So information is not exchanged between, and submitted to, in-house information systems multiple times.

- Reliability: When information is exchanged in a coordinated manner and it is re-used by multiple parties the quality of information will improve. Then transport can be scheduled better, leading to a higher reliability.

- Transit time: When information is known in advance instead of being delayed, a container can be cleared and picked up from the terminal as soon as possible. This can improve the transit time.

- Safety: When authorities and fire brigades know which trains or barges move hazardous cargo and know their location, accidents can be solved before turning into disasters (KNV, 2013).

- Costs: When more information is known about the different options for hinterland transport shippers can easily switch between different transport modes. When a client knows the different rail and barge connections between the port and his final destination in the hinterland, when these connections will leave and arrive and how much the transport will cost, the organisation is able to quickly move between different modalities.

\section{Conclusions}

This study is among the handful papers to go one level deeper into the subject of standardisation in intermodal transportation. It combines a literature review and an empirical part based on desk research and interviews. The findings show potential for the 
MABR

4,2

use of standards in three main areas of intermodal transport: infrastructure, loading units, and information exchange. The interviewees argue that official European standards are needed. In fact, however, transport standardisation is shifting to standards on a world-wide level. A limitation of this qualitative study is that it relies on perceptions of interviewees, though where possible triangulated with written sources. A second limitation is that the respondents of the study were all Dutch. This may lead to a difference in emphasis. In most European Member States, for example, barge transport is not as widely used as in The Netherlands. Finally, as most respondents in the interviews are active in the operational domain of intermodal transportation, they see potential for information exchange. But the standardisation consultant also mentioned quality and environmental standards. Maybe the market has not yet discovered the relevance of such standards.

\section{References}

Bask, A.H., Juga, J. and Laine, J. (2001), "Problems and prospects for intermodal transport: theoretical tools for practical breakthroughs?", 17th Annual IMP Conference Hosted by Norwegian School of Management BI, 9th-11th September, pp. 1-23.

Bontekoning, Y. and Priemus, H. (2004), "Breakthrough innovations in intermodal freight transport", Transportation Planning and Technology, Vol. 27 No. 5, pp. 335-345.

Bontekoning, Y.M., Macharis, C. and Trip, J.J. (2004), "Is a new applied transportation research field emerging? - A review of intermodal rail-truck freight transport literature", Transportation Research Part A, Vol. 38, pp. 1-34.

Caris, A., Macharis, C. and Janssens, G.K. (2008), "Planning problems in intermodal freight transport: accomplishments and prospects", Transportation Planning and Technology, Vol. 31 No. 3, pp. 277-302.

Carlo, H.J., Vis, I.F.A. and Roodbergen, K.J. (2013), "Seaside operations in container terminals: literature overview, trends, and research directions", Flexible Services and Manufacturing Journal, Vol. 27 Nos 2/3, pp. 224-262.

Carlo, H.J., Vis, I.F.A. and Roodbergen, K.J. (2014a), "Storage yard operations in container terminals: literature overview, trends, and research directions", European Journal of Operational Research, Vol. 235 No. 2, pp. 412-430.

Carlo, H.J., Vis, I.F.A. and Roodbergen, K.J. (2014b), "Transport operations in container terminals: literature overview, trends, research directions and classification scheme", European Journal of Operational Research, Vol. 236 No. 1, pp. 1-13.

Clark, T. and Jones, R. (1999), "Organisational interoperability maturity model for C2", Proceedings of the 1999 Command and Control Research and Technology Symposium.

Christiansen, M., Fagerholt, K. and Ronen, D. (2004), "Ship routing and scheduling: status and perspectives", Transportation Science, Vol. 38 No. 1, pp. 1-18.

Christiansen, M., Fagerholt, K., Nygreen, B. and Ronen, D. (2007), "Chapter 4: maritime transportation", in Barnhart, C. and Laporte, G. (Eds), Transportation, Handbooks in Operations Research and Management Science, Vol. 14, Elsevier, pp. 189-284.

Christiansen, M., Fagerholt, K., Nygreen, B. and Ronen, D. (2013), "Ship routing and scheduling in the new millennium", European Journal of Operational Research, Vol. 228 No. 3, pp. 467-483.

Cosmos Project (2013), "Intermodal transport in South East Europe - terms and definitions", available at: www.intermodal-cosmos.eu/content/intermodal-transport-in-south-east-europe/intermodalbasics/terms-and-definitions/index_eng.html (accessed 12 December 2013).

De Vries, H.J. (1997), "Standardization, what's in a name?", Terminology - International Journal of Theoretical and Applied Issues in Specialized Communication, Vol. 4 No. 1, pp. 55-83. 
Dullaert, W., Neutens, T., Vanden Berghe, G., Vermeulen, T., Vernimmen, B. and Witlox, F. (2009), "MamMoeT: an intelligent agent-based communication support platform for multimodal transport”, Expert Systems with Applications, Vol. 36 No. 7, pp. 10280-10287.

Egyedi, T.M. (1996), "The standardized container: gateway technologies in the system of cargo transportation", Workshop on Standardisation and Transportation, Helsinki, 23-24 August.

Egyedi, T.M. (2001), "Infrastructure flexibility created by standardized gateways: the cases of XML and the ISO container", Knowledge, Technology and Policy, Vol. 14 No. 3, pp. 41-54.

Eisenkopf, A., Kirchner, C., Jarzembowski, G., Ludewig, J., Rothengatter, W. and McCullough, G. (2006), "The liberalisation of rail transport in the EU", Intereconomics, Vol. 41 No. 6, pp. 292-313.

Eurostat (2013), "Modal split of freight transport", available at: http:/ec.europa.eu/eurostat/data/ database (accessed 24 March 2016).

European Commission (2004), "Proposal COM(2004) 361 for a European Parliament and Council directive on intermodal loading units".

European Conference of Ministers of Transport and European Commission (2001), Terminology on Combined Transport (PDF), Economic Commission for Europe (UN), New York, NY and Geneva, pp. 17-18.

Fransoo, J.C. and Lee, C.Y. (2013), "The critical role of ocean container transport in global supply chain performance", Production and Operations Management, Vol. 22 No. 2, pp. 253-268.

Galvao, C.B., Gharehgozli, A. and Mileski, J. (2018), "Being left at the altar: a content analysis of the ports of Houston and Galveston merger case that never happened", Research in Transportation Business and Management, Vol. 26, pp. 34-44.

Gharehgozli, A.H. and Zaerpour, N. (2018), "Stacking outbound barge containers in an automated deepsea terminal”, European Journal of Operational Research, Vol. 267 No. 3, pp. 977-995.

Gharehgozli, A.H., De Koster, R. and Jansen, R. (2017a), "Collaborative solutions for inter terminal transport”, International Journal of Production Research, Vol. 55 No. 21, pp. 6527-6546.

Gharehgozli, A.H., Laporte, G., Yu, Y. and De Koster, R. (2015), "Scheduling twin yard cranes in a container block", Transportation Science, Vol. 49 No. 3, pp. 686-705.

Gharehgozli, A.H., Mileski, J. and Duru, O. (2017b), "Heuristic estimation of container stacking and reshuffling operations under the containership delay factor and mega-ship challenge", Maritime Policy and Management, Vol. 44 No. 3, pp. 373-391.

Gharehgozli, A.H., Roy, D. and de Koster, R. (2016), "Sea container terminals: new technologies and or models", Maritime Economics and Logistics, Vol. 18 No. 2, pp. 103-140.

Gharehgozli, A.H., Vernooij, F.G. and Zaerpour, N. (2017c), "A simulation study of the performance of twin automated stacking cranes at a seaport container terminal", European Journal of Operational Research, Vol. 261 No. 1, pp. 108-128.

Gharehgozli, A.H., Mileski, J., Adams, A. and von Zharen, W. (2017d), "Evaluating a 'Wicked problem': a conceptual framework on seaport resiliency in the event of weather disruptions", Technological Forecasting and Social Change, Vol. 121, pp. 65-75.

Gharehgozli, A.H., Yu, Y., De Koster, R. and Udding, J.T. (2014a), "A decision-tree stacking heuristic minimising the expected number of reshues at a container terminal", International Journal of Production Research, Vol. 52 No. 9, pp. 2592-2611.

Gharehgozli, A.H.Y., Yu, Y., de Koster, R. and Udding, J.T. (2014b), “An exact method for scheduling a yard crane”, European Journal of Operational Research, Vol. 235 No. 2, pp. 431-447.

Gorman, M., Clarke, J.P., Gharehgozli, A.H., Hewitt, M., de Koster, R. and Roy, D. (2014), "State of the practice: application of or/MS in freight transportation", Interfaces, Vol. 44 No. 6, pp. 535-554.

INeS Danube (2016), "INeS Danube information platform on intermodal inland navigation", available at: www.ines-danube.info/goto.php?target=root_1\&client_id=viailias4 (accessed 25 March 2016). 
MABR

4,2

ISO/IEC (2004), ISO/IEC Guide 2: Standardization and Related Activities - General Vocabulary, 8th ed., International Organization of Standardization/International Electrotechnical Commission, Geneva.

Janic, M. (2001), "Integrated transport systems in the European union: an overview of some recent developments", Transport Reviews, Vol. 21 No. 4, pp. 469-497.

KNV (2013), "IGS komt eraan”, available at: www.knv.nl/nieuws/941/igs_komt_eraan (accessed 15 December 2013).

Konings, J.W. (2008), The Future of Intermodal Freight Transport: Operations, Design and Policy, in Priemus, H. and Nijkamp, P. (Eds), Edward Elgar Publishing.

Lee, C.Y. and Song, D.P. (2017), "Ocean container transport in global supply chains: overview and research opportunities", Transportation Research Part B: Methodological, Vol. 95, pp. 442-474.

Lehr, W. (1995), “Compatibility standards and interoperability: lessons from the internet”, in Kahin, B. and Abbate, J. (Eds), Standards Policy for Information Infrastructure, MIT Press, Boston, MA, p. 653.

Marinov, M. (2009), "Rail and multimodal freight: a problem-oriented survey (part II-1"), Problemy Transportu, Vol. 4, pp. 73-83.

Meng, Q., Wang, S., Andersson, H. and Thun, K. (2014), “Containership routing and scheduling in liner shipping: overview and future research directions", Transportation Science, Vol. 48 No. 2, pp. 265-280.

Merkel, A. (2018), "Competitive intensity and inefficiency in European container ports: an empirical investigation using SFA", Maritime Business Review, Vol. 3 No. 2, pp. 165-184.

Meyer, N. (2012), "Political contestation under the shadow of hierarchy: European intermodal transport standardization and the threat of mandatory compliance”, LSE 'Europe in Question' Discussion Paper Series.

Mileski, J., Gharehgozli, A., Ghoram, L. and Swaney, R. (2018), "Cooperation in developing a disaster prevention and response plan for arctic shipping”, Marine Policy, Vol. 92, pp. 131-137.

Motraghi, A. (2013), "Rail research projects: case studies", Research in Transportation Economics.

Reis, V., Fabian Meier, J., Pace, G. and Palacin, R. (2012), "Rail and multi-modal transport", Research in Transportation Economics.

Railcargo (2013), Spoor in Cijfers, De Swart, Den Haag.

Ronen, D. (1993), "Ship scheduling: the last decade", European Journal of Operational Research, Vol. 71 No. 3, pp. 325-333.

Sakalys, A. and Palšaitis, R. (2006), "Development of intermodal transport in new european union states", TRANSPORT, Vol. 21 No. 2, pp. 148-153.

Silborn, H. (2013), "Measures promoting intermodal transport as an alternative to pure road transport", Proceedings of the International Conference on Heavy Vehicles, HVTT10: 10th International Symposium on Heavy Vehicle Transportation Technologies, Vol. 60, p. 57.

Sharifyazdi, M., Navangul, K.A., Gharehgozli, A. and Jahre, M. (2018), "On- and offshore prepositioning and delivery mechanism for humanitarian relief operations", International Journal of Production Research, Vol. 56 No. 18, pp. 6164-6182.

Stahlbock, R. and Voß, S. (2008), "Operations research at container terminals: a literature update", Or Spectrum, Vol. 30 No. 1, pp. 1-52.

Steenken, D., Voß, S. and Stahlbock, R. (2004), "Container terminal operation and operations research a classification and literature review”, Or Spectrum, Vol. 26 No. 1, pp. 3-49.

Stölzle, W., Bendul, D.W.I.J. and Kudla, D.L.N. (2009), "Intermodal transport and supply chains", Transportation for a Global Economy Forum: challenges and opportunities in the downturn. Leipzig.

Sys, C. and Vanelslander, T. (Eds) (2011), Future Challenges for Inland Navigation: A Scientific Appraisal of the Consequences of Possible Strategic and Economic Developments up to 2030, ASP/VUBPRESS/UPA. 
Tran, N.K. and Haasis, H.D. (2015), "Literature survey of network optimization in container liner shipping", Flexible Services and Manufacturing Journal, Vol. 27 No. 2-3, pp. 139-179.

Tomlinson, J. (2009), History and Impact of the Intermodal Shipping Container, Pratt Institute, For LIS 654-05/Carrie Bickner.

Transport en Logistiek Nederland (2008), Focus op Intermodaal Vervoer, Zoetermeer.

Tsamboulas, D., Vrenken, H. and Lekka, A.M. (2007), "Assessment of transport policy potential for intermodal mode shift on a european scale", Transport Res A, Vol. 41 No. 8, pp. 715-733.

Van de Lande, P. and Henriques, M. (2006), Integrated Services in the Intermodal Chain: Will It Improve Freight Mobility in Europe?

Vis, I.F.A. and De Koster, R. (2003), “Transshipment of containers at a container terminal: an overview”, European Journal of Operational Research, Vol. 147 No. 1, pp. 1-16.

Wiegmann, P.M. (2013), "Combining different modes of stadnard setting - analysing strategies and the case of connectors for charging electric vehicles in Europe", in Jakobs, K., de Vries, H.J. Ganesh, A., Gulacsi, A. and Soetert, I. (Eds), EURAS Proceedings 2013 - Stadnards: Boosting European Competitiveness, pp. 397-411.

Woxenius, J. and Bergqvist, R. (2011), "Comparing Maritime containers and semi-trailers in the context of hinterland transport by rail", Journal of Transport Geography, Vol. 19 No. 4, pp. 680-688.

\section{Appendix. Interview questions}

\section{Identifying problems in intermodal transport}

- In which parts of the intermodal chain do problems or possibilities for improvement occur and what are these possibilities?

- What possibilities for improvement are possible at the interface between two different modes of transport?

- What possibilities for improvement are possible due to different procedures for two or more countries?

\section{Identifying the cause of the problems and identify stakeholders}

- Why do these problems occur? Do they occur due to a lack of collaboration, coordination and/or alignment?

- Which stakeholders are involved in the problems?

- What are the stakes of these actors? Why is there no collaboration/coordination/ alignment?

- Are there any previous attempts to coordinate processes?

\section{Possibilities of standardisation}

- What standards is the company currently using?

- Can standards solve the problem or are other solutions needed?

- Are the official European harmonised standards often used to meet the requirements set by the European commission or do companies find other ways to meet these requirements?

- What types of standards would be the best solution to the current problems? (formal standards vs. consortium or company standards) 
MABR

4,2

168

- On what level are possible standards necessary? (company, chain-wide, national, European or world-wide?)

The decision-making process for successful standards

- Which actors need to be involved in the setting of standards?

- Which actors are critical in the process?

- What are critical success factors for the development and implementation of standards?

- How to break through the lock-in?

- What can be improved in the decision-making process to further improve the quality of standards?

\section{Corresponding author}

Amir Gharehgozli can be contacted at: Amir.gharehgozli@csun.edu

For instructions on how to order reprints of this article, please visit our website: www.emeraldgrouppublishing.com/licensing/reprints.htm

Or contact us for further details: permissions@emeraldinsight.com 